\title{
Optimasi Bobot Jaringan Syaraf Tiruan Mengunakan Particle Swarm Optimization
}

\author{
Harry Ganda Nugraha*1 dan Azhari $\mathrm{SN}^{2}$ \\ ${ }^{1}$ Mahasiswa Program Pascasarjana Ilmu Komputer, FMIPA, UGM, Yogyakarta. \\ ${ }^{2}$ Staf pengajar Program Pascasarjana Ilmu Komputer, FMIPA, UGM, Yogyakarta. \\ e-mail: *11 gandaharry22@yahoo.com, ${ }^{2}$ arisn@ugm.ac.id
}

\begin{abstract}
Abstrak
Masalah peramalan adalah masalah yang sering ditemukan dalam proses pengambilan keputusan. Tool yang cukup populer untuk menangani masalah peramalan adalah jaringan syaraf tiruan. Jaringan syaraf tiruan banyak digunakan karena kemampuannya untuk meramalkan data nonlinear time series. Algoritma pembelajaran yang sering digunakan untuk memperbaiki bobot pada jaringan syaraf tiruan adalah backpropagation. Namun proses pembelajaran backpropagation terkadang menemui kendala seperti over fiting sehingga tidak dapat menggeneralisasi masalah. Untuk mengatasi masalah tersebut diusulkan penggunaan particle swarm optimization untuk melatih bobot pada jaringan. Performa dari masing-masing model akan diukur dengan mean square error, mean absolute percentage error, normalized mean square error, prediction of change in direction, average relative variance. Untuk keperluan analisis model digunakan data time series inflasi di indonesia. Metode yang diusulkan menunjukan sistem jaringan hybrid mampu menangani masalah peramalan data time series dengan performa mendekati jaringan syaraf tiruan backpropagation.
\end{abstract}

Kata kunci-jaringan syaraf tiruan, particle swarm optimization, prediction of change in direction, average relative variance .

\begin{abstract}
Forecasting problem is common problem that easily found in decision making process. The popular tool to handle that problem is artificial neural network. Artificial neural network have been widely use because its ability to forecast nonlinear time series data. The learning method that have been widely use to train artificial neural network weight is backpropagation. Otherwise backpropagation learning process sometimes find problem such as over fiting so it can't generalized the problem. Particle swarm optimization method had been proposed to train artificial neural network weigth. Mean square error, mean absolute percentage error, normalized mean square error, prediction of change in direction, average relative variance had been use to measures the model performance. Indonesia inflation time series data had been use to analyzed the model. The proposed method show that hybrid system could handle the time series forecasting problem as good as backpropagation artificial neural network
\end{abstract}

Keywords - artificial neural network, particle swarm optimization, prediction of change in direction, average relative variance.

Received December $1^{\text {st }}$ 2013; Revised January $1^{\text {st }}$, 2013; Accepted January $15^{\text {th }}$, 2014 


\section{PENDAHULUAN}

$\mathrm{M}^{2}$ asalah peramalan merupakan masalah yang banyak dihadapi pada berbagai bidang persoalan antara lain ramalan cuaca [1], peramalan beban listrik [2], peramalan penggunaan pembangkit listrik tenaga angin [3], dan lain sebagainya. Salah satu bidang permasalahan yang sering diteliti adalah adalah bidang finansial. Peramalan dalam bidang finansial memiliki peran yang cukup penting karena hasil peramalaan digunakan sebagai alat untuk membantu para pembuat keputusan menangani problem konkrit dalam framework teknologi, memberikan informasi peramalan data masa depan berdasarkan data historis yang telah terjadi [4]. Masalah peramalan pada bidang finansial bisa menyangkut banyak objek antara lain peramalan tingkat inflasi [5], harga emas [6], nilai tukar mata uang [7], dan lain sebagainya.

Tingkat inflasi tahunan penting untuk diketahui karena merupakan indikator keadaan ekonomi masyarakat di suatu negara dan mempengaruhi kebijakan yang akan diambil oleh pemerintah [5]. Inflasi dapat diukur dengan menghitung persentase perubahan sebuah indeks harga, diantaranya adalah indeks harga konsumen (IHK), indeks biaya hidup (COLI), indeks harga produsen (IHPB), indeks harga komoditas, indeks harga barang-barang modal, dan deflator PDB [8].

Keakuratan peramalaan adalah salah satu faktor penting di dalam pemilihan metode peramalan [9]. Metode peramalan yang memiliki tingkat error data cukup rendah dan cukup baik dalam proses generalisasi adalah Artificial Neural Network [5]. Dengan data training yang cukup dan proses pembelajaran penyesuaian bobot yang tepat diharapkan model ini mampu untuk meramalkan data time series untuk beberapa periode waktu ke depan.

Metode pelatihan yang biasa digunakan untuk memperbaiki bobot dalam jaringan syaraf tiruan adalah backpropagation. Namun pada penerapannya metode ini masih memiliki beberapa kelemahan diantaranaya adalah masalah waktu pelatihan yang lama untuk mencapai konvergen, dan juga masalah overfitting pada jaringan syaraf tiruan. Selain itu penentuan parameter pelatihan seperti learning rate dan momentum yang tepat dalam proses pelatihan juga menjadi kendala tersendiri.

Untuk mengatasi masalah optimalisasi bobot jaringan maka digunakan Particle Swarm Optimization (PSO), karena merupakan salah satu teknik AI terbaik untuk optimasi dan perkiraan parameter [9]. Penggunaan optimasi pada bobot jaringan syaraf tiruan akan mempercepat waktu kalkulasi pada proses selanjutnya untuk mencapai keadaan konvergen. Model akan dievaluasi dengan mengaplikasikannya pada observasi tingkat inflasi pertahun dan membandingkan hasilnya dengan metode sebelumnya menggunakan beberapa metode pengukuran error.

Penelitian akan fokus pada penerapan particle swarm optimization sebagai metode palatihan bobot jaringan syaraf tiruan. Model yang dibuat diharapkan mampu untuk meramalkan data time series dengan error hasil peramalan yang kecil, jadi model ini bisa dipertimbangkan sebagai tool alternatif dalam pelatihan jaringan syaraf tiruan.

\section{METODE PENELITIAN}

Proses awal yang dilakukan pada sistem peramalan tingkat inflasi ini adalah menerima masukan nilai parameter dari user berupa jumlah neuron input, jumlah neuron pada hidden layer, epoch, jumlah partikel, c1, c2, inertia max, inertia min, maksimal MSE, dan time lag. Proses berikutnya sistem akan mengambil data latih dari database. Data ini akan di normalisasi sebelum dijadikan input jaringan syaraf tiruan. Normalisasi dilakukan karena jaringan syaraf menggunakan fungsi aktivasi sigmoid yang keluaran berada pada range nilai 0 sampai 1 , selain itu normalisasi juga dilakukan untuk menghindari dominasi dari variabel yang bernilai besar terhadap variabel bernilai kecil. Normalisasi dilakukan dengan mengubah nilai dari data ke dalam rentang nilai nol sampai satu. Proses selanjutnya adalah melatih jaringan syaraf tiruan untuk mendapatkan bobot akhir. Proses pelatihan menggunakan particle swarm optimization.

IJCCS Vol. 8, No. 1, January $2014: 25-36$ 
Bobot pada jaringan syaraf tiruan direpresentasikan kedalam matriks posisi pada partikel PSO. Selanjutnya dilakukan proses pencarian posisi terbaik pada PSO. Posisi terbaik pada PSO akan menjadi bobot akhir pada jaringan syaraf tiruan. Jaringan syaraf tiruan yang telah dilatih akan diuji dengan menggunakan data uji yang diambil dari database. Hasil dari pengujian adalah persentase peramalan, dan selanjutnya akan dilakukan analisis parameter jaringan terhadap akurasi hasil dari peramalan. Gambar alur sistem dapat dilihat pada Gambar 1.

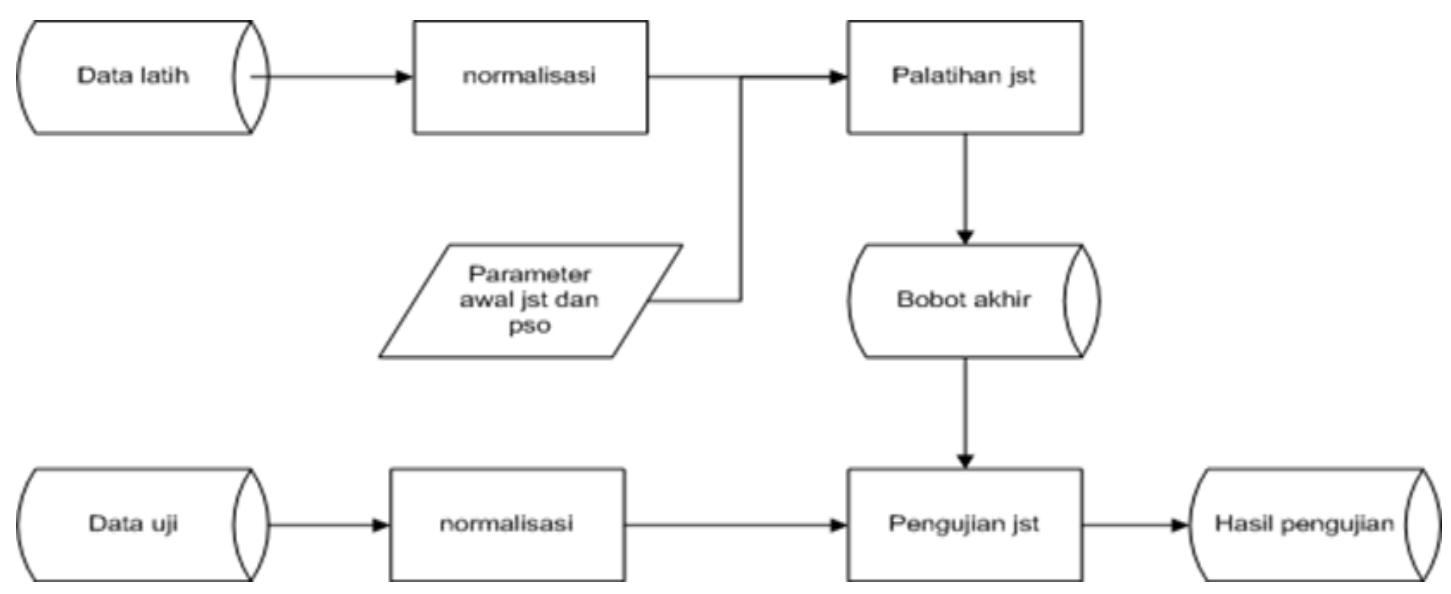

Gambar 1 Bagan proses sistem peramalan inflasi

Flowchart keseluruhan sistem prediksi tingkat inflasi dapat dilihat dari Gambar 2. Beberapa proses untuk peramalan tingkat inflasi antara lain:

1. Proses input parameter, pada proses ini user akan diminta memasukan parameter awal yaitu jumlah neuron input, jumlah neuron pada hidden layer, epoch, jumlah partikel, c1, c2, inertia max, inertia min, maksimal MSE, dan time lag.

2. Proses normalisasi data latih menjadi interval nol sampai satu.

3. Proses inisialisasi, merupakan proses penentuan bobot pada JST. Proses penentuan bobot awal ini menggunakan PSO. Untuk setiap partikel pada PSO akan dinilai posisi terbaiknya dengan mengimplementasikannya pada JST.

4. Proses pelatihan, merupakan proses pelatihan jaringan dengan metode back propagation. pada proses ini bobot akan disesuaikan sehingga dapat menghasilkan hasil peramalan yang sesuai target dengan error kecil.

5. JST yang sudah terlatih akan diuji dengan data baru.

Rancangan data flow diagram level 0 dari sistem prediksi inflasi dapat dilihat pada Gambar 2. Aliran data yang terjadi pada DFD level 0 di Gambar 3 adalah data latih, data uji, jumlah neuron input dan hidden pada JST, epoch, learning rate, momentum, dan max MSE akan dimasukan oleh pengguna ke dalam sistem. Dan setelah data diproses dengan melakukan pelatihan dan pengujian pada sistem maka keluaran dari sistem adalah berupa hasil prediksi dan MSE akhir. 


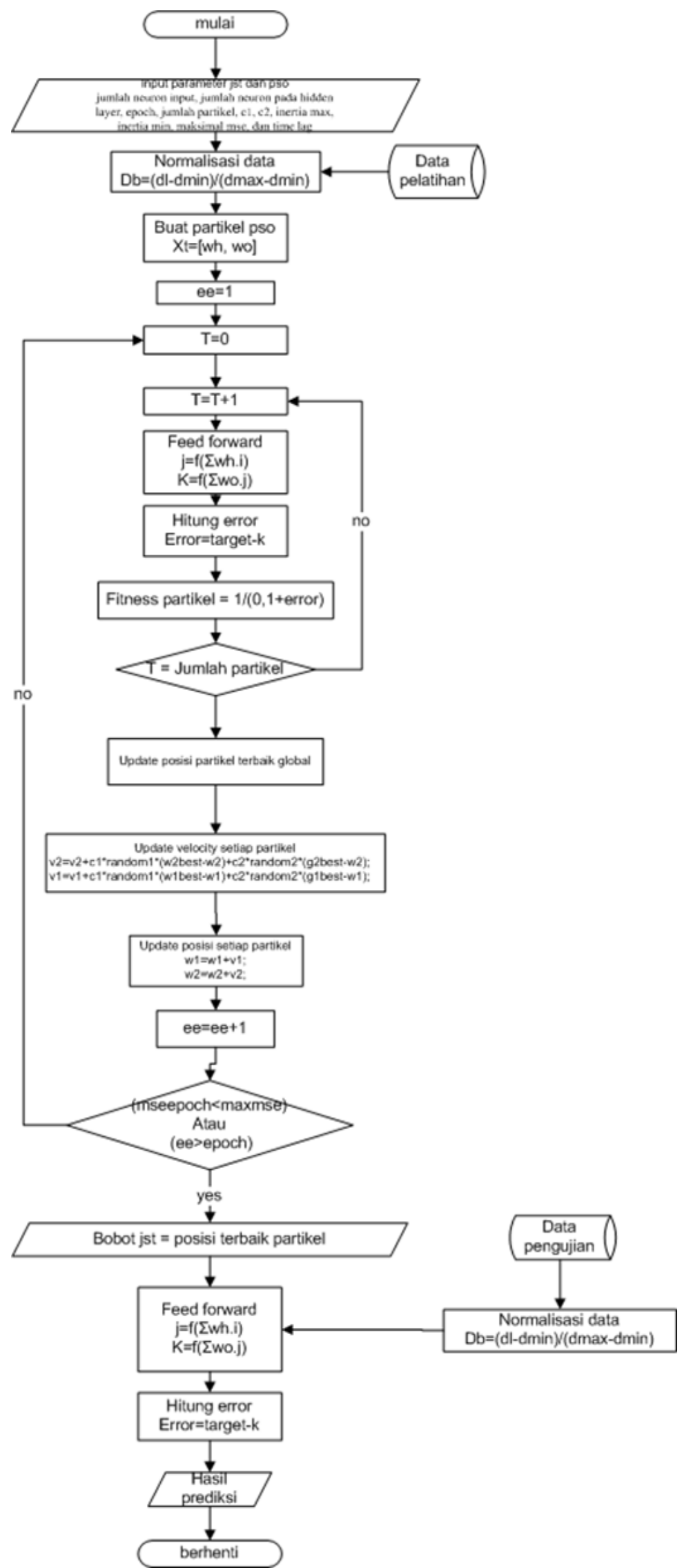

Gambar 2 Flowchart system

IJCCS Vol. 8, No. 1, January $2014: 25$ - 36 


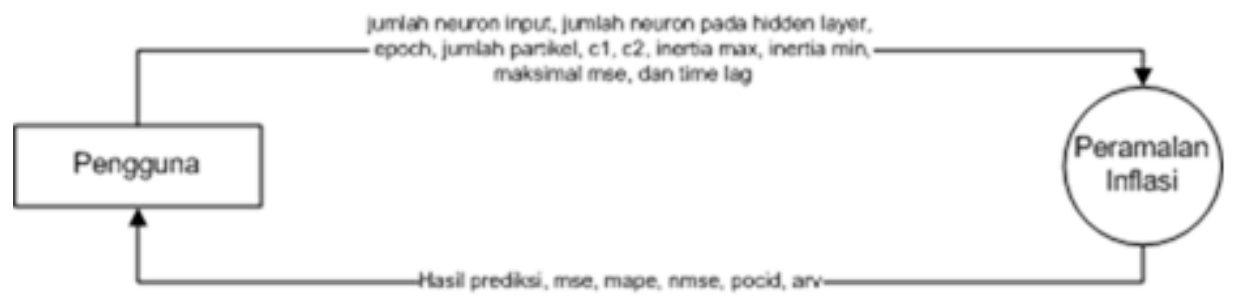

Gambar 3. DFD level 0 sistem peramalan inflasi

JST yang digunakan untuk sistem peramalan ini memiliki duabelas neuron input dan satu neuron output. Jumlah neuron pada hidden layer tidak ditentukan karena merupakan salah satu variabel yang akan diteliti pengaruhnya terhadap hasil keluaran dari jaringan. Layer input dan hidden dalam jaringan masing - masing memiliki satu bias. Arsitektur JST yang digunakkan dalam penelitian ini dapat dilihat pada Gambar 4 dan Gambar 5.

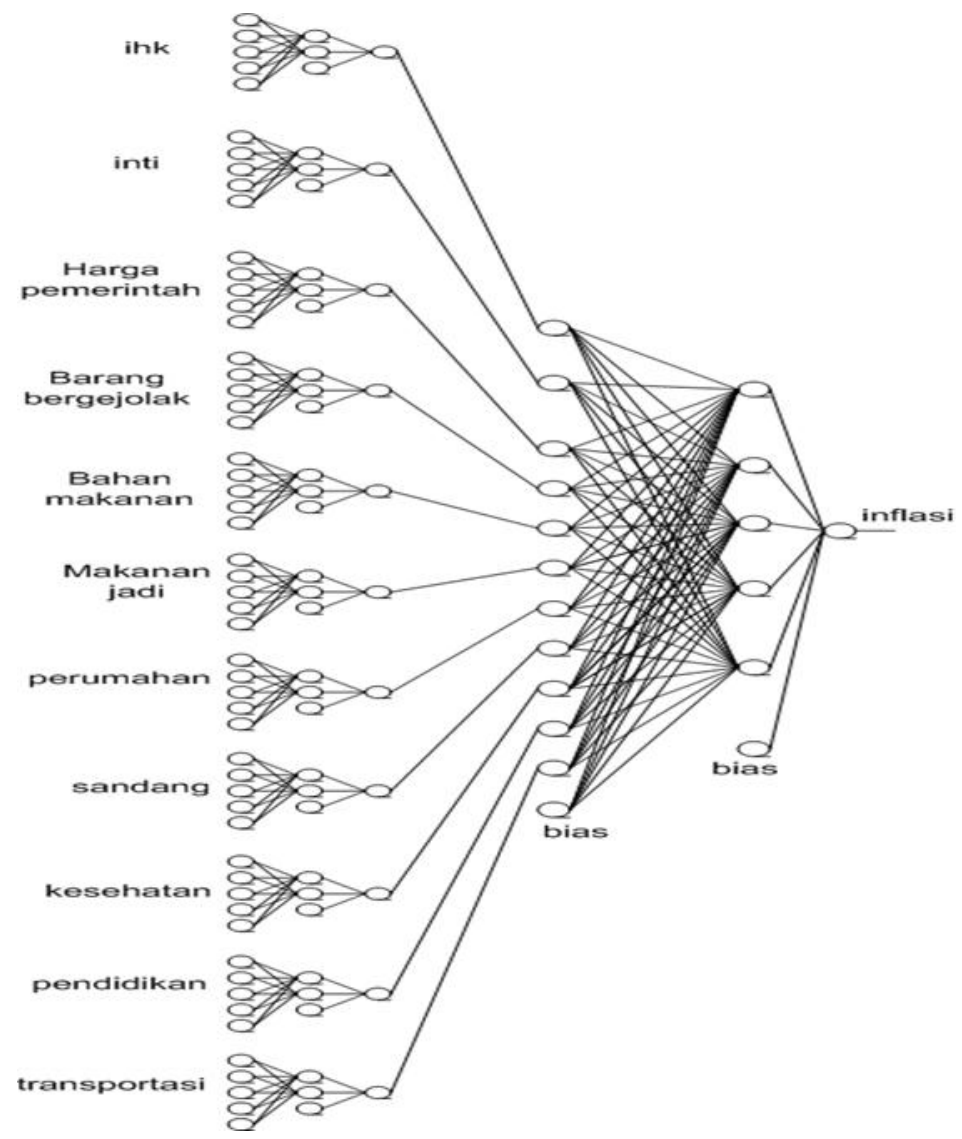

Gambar 4 Arsitektur jaringan syaraf tiruan

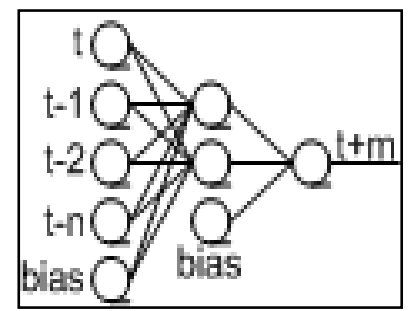

Gambar 5 Arsitektur sub jaringan syaraf tiruan 
Input layer terdiri dari 11 neuron yaitu kelompok bahan makanan, kelompok makanan jadi, minuman, dan tembakau, kelompok perumahan, kelompok sandang, kelompok kesehatan, kelompok pendidikan dan olah raga, kelompok transportasi dan komunikasi, indeks inti, indeks harga yang diatur pemerintah, indeks barang bergejolak, indeks harga konsumen.

Jumlah hidden layer yang dipakai pada penelitian ini adalah satu hidden layer dengan jumlah neuron pada hidden layer berupa variabel antara 1 sampai 10 untuk menguji pengaruhnya terhadap keakuratan hasil peramalan. Output layer terdiri dari satu neuron yaitu tingkat inflasi.

Pelatihan jaringan syaraf tiruan sistem prediksi akan menggunakan particle swarm optimization. Setiap partikel dari PSO akan berisi bobot input ke hidden dan bobot hidden ke output dari JST. Gambar rancangan partikel dapat dilihat pada Gambar 6 ,Wih adalah bobot jaringan antara neuron input dan neuron hidden. Who adalah bobot jaringan antara neuron hidden dan neuron output.

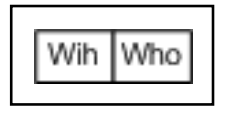

Gambar 6. Rancangan partikel PSO

Sistem membutuhkan input untuk proses pelatihan dan pengujian jaringan syaraf tiruan. Data yang digunakan dalam penelitian ini adalah data yang mempengaruhi tingkat inflasi, yaitu indeks harga konsumen untuk kelompok bahan makanan, kelompok makanan jadi, minuman dan tembakau, kelompok perumahan, kelompok sandang, kelompok kesehatan, kelompok pendidikan dan olahraga, kelompok transportasi dan komunikasi, indeks inti, indeks harga yang diatur pemerintah, indeks barang bergejolak, jumlah uang beredar di Indonesia. Data yang menjadi target adalah indeks inflasi bulanan.

Data untuk penelitian ini diambil dari badan pusat statistik, yaitu data inflasi bulanan dari tahun 2006 sampai 2012. Data dibagi kedalam dua kelompok, yaitu kelompok data latih sebanyak 70\% dari keseluruhan data, dan kelompok data uji sebanyak 30\%.Data yang digunakan adalah data sekunder yang didapat dari badan pusat statistik (BPS). Contoh data masukan untuk sistem pada periode waktu januari sampai mei 2009 ada pada Tabel 1. Data pelatihan akan dinormalisasi sebelum dijadikan input pada JST. Data yang sudah dinormalisasi bisa dilihat pada Tabel 2. Proses normalisasi menjadikan nilai data input menjadi rentang nilai nol sampai satu. Persamaan yang digunakan untuk melakukan normalisasi dapat dilihat pada persamaan 1.

Tabel 1 Data pelatihan

\begin{tabular}{|c|c||c|c|c|c|c|c|c|c|c|c|c|}
\hline Bulan & A & B & C & D & E & F & G & H & I & J & K & L \\
\hline Januari & 0,44 & $-2,67$ & 0,79 & 0,76 & 0,95 & $-0,06$ & 0,55 & 0,37 & 0,12 & $-2,53$ & 113,78 & $-0,07$ \\
\hline February & 0,68 & $-2,2$ & 0,98 & 0,95 & 0,91 & 0,28 & 2,85 & 0,17 & 0,04 & $-2,43$ & 114,02 & 0,21 \\
\hline Maret & 0,46 & 0,04 & $-0,4$ & $-0,26$ & 0,52 & 0,2 & 1,02 & 0,73 & 0,06 & 0,25 & 114,27 & 0,22 \\
\hline April & $-0,04$ & 0,14 & $-1,53$ & $-1,33$ & 0,4 & 0,12 & $-1,7$ & 0,34 & 0,05 & 0,07 & 113,92 & $-0,31$ \\
\hline mei & 0,13 & 0,04 & $-0,27$ & $-0,25$ & 0,48 & 0,09 & $-0,48$ & 0,62 & 0,07 & 0 & 113,97 & 0,04 \\
\hline
\end{tabular}

IJCCS Vol. 8, No. 1, January 2014 : 25 - 36 
Tabel 2 Data pelatihan ternormalisasi

\begin{tabular}{|c||c|c|c||c|c|c|c|c|c|c|c|c|}
\hline Bulan & A & B & C & D & E & F & G & H & I & J & K & L \\
\hline \hline Januari & 0,43 & 0 & 0,4 & 0,41 & 0,43 & 0 & 0,47 & 0,46 & 0,05 & 0 & 0 & 0,13 \\
\hline February & 0,64 & 0,09 & 0,42 & 0,44 & 0,41 & 0,21 & 0,95 & 0,16 & 0,01 & 0,02 & 0,01 & 0,28 \\
\hline Maret & 0,44 & 0,57 & 0,25 & 0,25 & 0,19 & 0,16 & 0,57 & 1 & 0,02 & 0,69 & 0,03 & 0,29 \\
\hline April & 0 & 0,59 & 0,10 & 0,09 & 0,12 & 0,11 & 0 & 0,42 & 0,01 & 0,64 & 0,009 & 0,005 \\
\hline Mei & 0,15 & 0,57 & 0,26 & 0,26 & 0,16 & 0,09 & 0,26 & 0,84 & 0,03 & 0,63 & 0,01 & 0,19 \\
\hline
\end{tabular}

Keterangan :

$\mathrm{A}=$ Indeks inti.

$\mathrm{B}=$ Harga pemerintah.

$\mathrm{C}=$ Barang bergejolak.

$\mathrm{D}=$ Bahan makanan.

$\mathrm{E}=$ Makanan jadi.

$\mathrm{F}=$ Perumahan.
$\mathrm{G}=$ Sandang .

$\mathrm{H}=$ Kesehatan.

$\mathrm{I}=$ Pendidikan.

$\mathrm{J}=$ Tranportasi.

$\mathrm{K}=$ Indeks harga konsumen.

$\mathrm{L}=$ Tingkat inflasi.

$$
N^{\prime}=\frac{N-N_{\min }}{N_{\max }-N_{\min }}
$$

Dimana,

N' = Data yang sudah dinormalisasi.

$\mathrm{N} \quad=$ Data yang akan dinormalisasi.

$N_{\max }=$ Data terbesar dari himpunan data.

$N_{\min }=$ Data terkecil dari himpunan data.

Panel pelatihan

Panel pelatihan terdapat 10 masukan variabel, yaitu jumlah neuron input, jumlah neuron pada hidden layer, epoch, jumlah partikel, c1, c2, inertia max, inertia min, maksimal MSE, dan time lag. Pada panel pelatihan ini juga terdapat pop up menu yang berisi tabel data yang ingin dilatih oleh user. Keluaran dari panel pelatihan ini ada 6 yaitu nilai MSE, mape, n MSE, poc id, arv, dan epoch pelatihan. Dalam panel ini terdapat 4 grafik dan 6 tabel yang menggambarkan jalannya proses pelatihan. Grafik yang terdapat di panel pelatihan ini adalah grafik perbandingan target dan output, grafik MSE, mape dan n MSE. Tabel yang terdapat dalam panel pelatihan ini adalah tabel MSE, mape, n MSE, bobot input ke hidden, bobot hidden ke output, dan perbandingan target dan output. Terdapat dua tombol pada panel ini yaitu tombol belajar dan main menu. Rancangan antar muka dari panel pelatihan ditunjukan pada Gambar 1.

Panel pengujian

Panel pengujian terdapat pop up menu yang berisi nama tabel data yang ingin diuji. Keluaran dari panel ini berupa 3 buah grafik dan 3 buah tabel yaitu nilai error, perbandingan target dan output, hasil peramalan. Pada panel ini terdapat tiga buah tombol yaitu tombol uji, peramalan, dan main menu. Rancangan antar muka dari panel pengujian ditunjukan pada Gambar 2. 


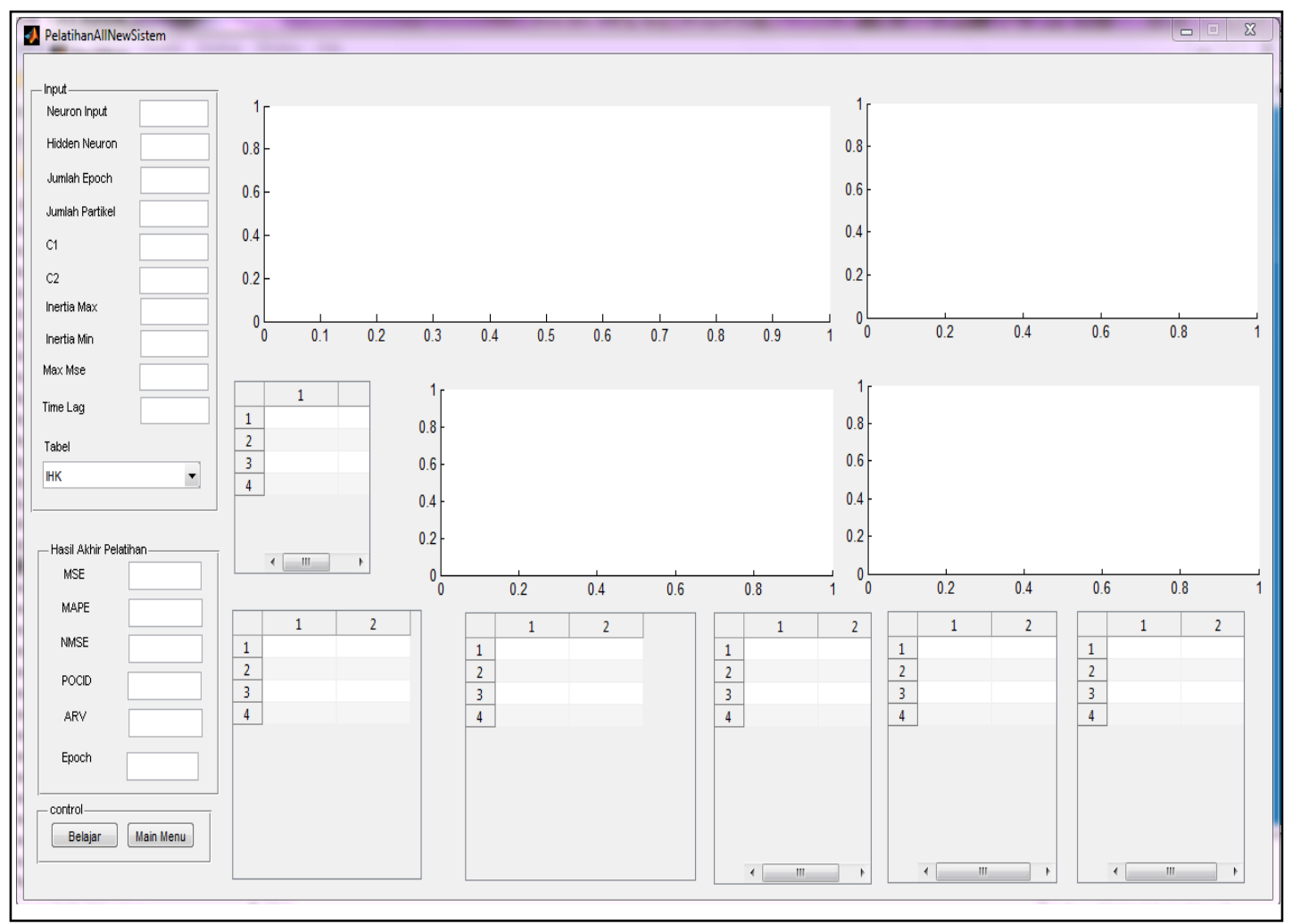

Gambar 1 Panel pelatihan

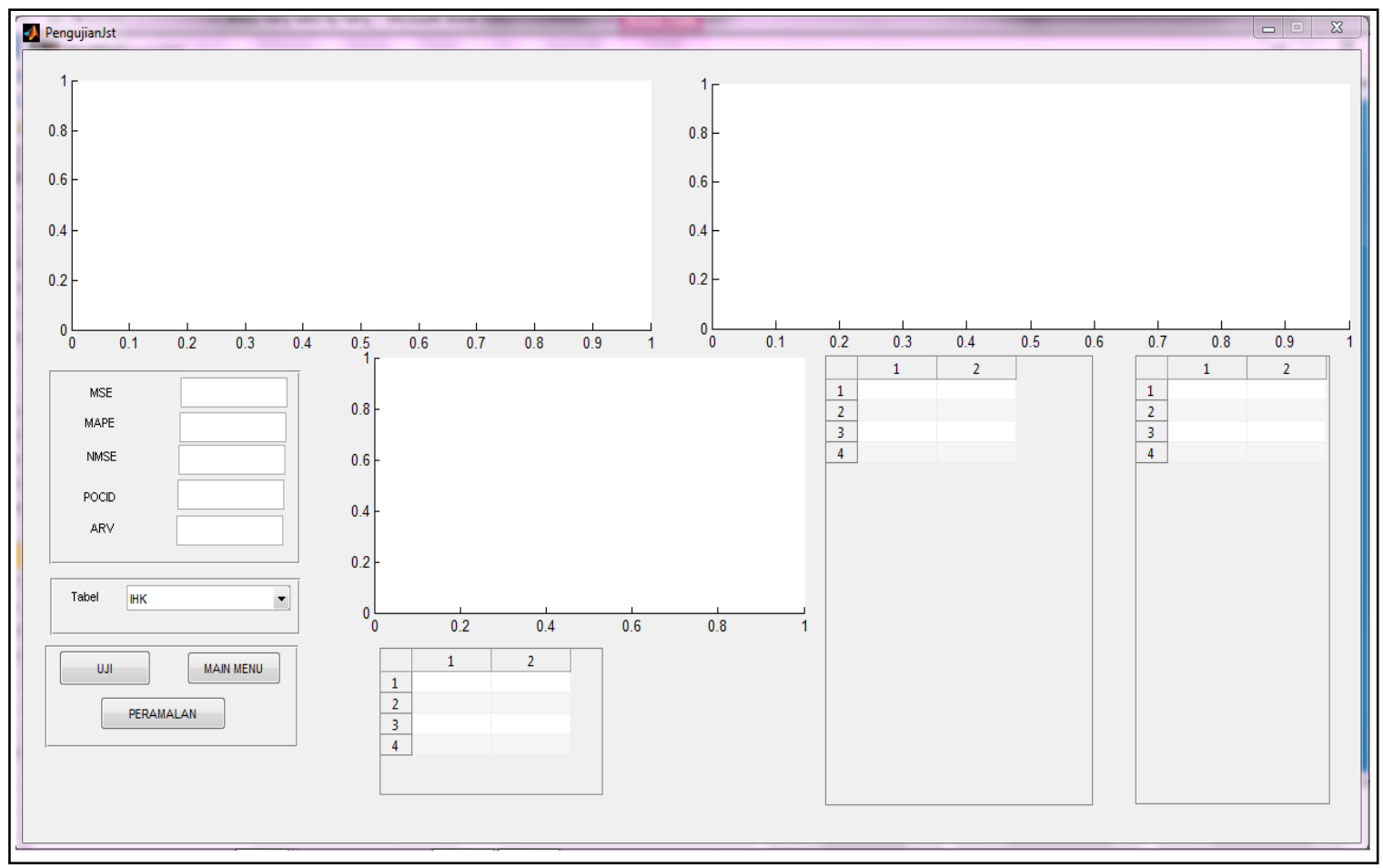

Gambar 2 Panel pengujian

IJCCS Vol. 8, No. 1, January 2014 : 25 - 36 


\section{HASIL DAN PEMBAHASAN}

Untuk mengetahui pengaruh algoritma optimasi particle swarm optimization pada proses pelatihan jaringan syaraf tiruan, maka dilakukan percobaan yang sama seperti pada pelatihan jaringan syaraf tiruan back propagation. Percobaan pertama adalah pelatihan pada jaringan syaraf tiruan dengan variabel masukan IHK. Parameter yang dilihat pengaruhnya adalah jumlah neuron input, jumlah neuron hidden, velocity, jumlah partikel. Jumlah input mulai dari 3 sampai 5 yang berarti dari t sampai $\mathrm{t}-2$, jumlah hidden neuron dari 4 sampai 5 , velocity minimum adalah 0 dan velocity maksimum antara 0,1 sampai 0,5 , jumlah partikel yang digunakan adalah 10, epoch yang digunakan adalah 10. Data hasil pelatihan dapat dilihat pada Tabel 3 .

Tabel 3 Hasil pelatihan JST hybrid

\begin{tabular}{|c|c|c|c|}
\hline percobaan & Arsitektur & Velocity & MSE \\
\hline 1 & $3-4-1$ & 0,2 & 0.068561 \\
\hline $\mathbf{2}$ & $\mathbf{3 - 5 - 1}$ & $\mathbf{0 , 3}$ & $\mathbf{0 . 0 4 2 7 9 7}$ \\
\hline 3 & $4-4-1$ & 0,4 & 0.07195 \\
\hline 4 & $4-5-1$ & 0,4 & 0.074493 \\
\hline 5 & $5-4-1$ & 0,5 & 0.073907 \\
\hline 6 & $5-5-1$ & 0,4 & 0.075538 \\
\hline
\end{tabular}

Proses pelatihan yang dilakukan dengan 6 kali percobaan, didapatkan hasil MSE terkecil pada percobaan ke-2, yaitu : velocity maksimum $=0,3$, arsitektur $=3-5-1$, MSE $=$ 0.042797 .

Percobaan berikutnya adalah pelatihan jaringan syaraf tiruan hybrid yang masukannya dari keluaran jaringan syaraf hybrid lainnya. Parameter jaringan antara lain jumlah neuron pada hidden layer dimulai dari satu neuron sampai lima neuron, jumlah partikel yang digunakan adalah 10, velocity maksimum dibuat bervariasi dari 0,1 sampai 0,5. Untuk parameter pemberhentian pelatihan jaringan ditentukan jumlah maksimum iterasi adalah 100. Data hasil pelatihan dapat dilihat pada Tabel 4.

Tabel 4 Hasil percobaan kedua JST hybrid

\begin{tabular}{|c|c|c|c|}
\hline percobaan & Arsitektur & Velocity & MSE \\
\hline 1 & $12-1-1$ & 0,4 & 0.070783 \\
\hline 2 & $12-2-1$ & 0,5 & 0.052454 \\
\hline $\mathbf{3}$ & $\mathbf{1 2 - 3 - 1}$ & $\mathbf{0 , 4}$ & $\mathbf{0 . 0 3 8 2 8 8}$ \\
\hline 4 & $12-4-1$ & 0,1 & 0.043646 \\
\hline 5 & $12-5-1$ & 0,5 & 0.077239 \\
\hline
\end{tabular}


Proses pelatihan yang dilakukan dengan 5 kali percobaan, didapatkan hasil MSE terkecil pada percobaan ke-3, yaitu : velocity $=0,4$, arsitektur $=12-3-1, \operatorname{MSE}=0.038288$.

Pada proses pengujian jaringan syaraf tiruan hybrid data yang digunakan berjumlah 33 data dari tahun 2009 sampai 2012 yaitu 30\% data dari data keseluruhan. Hasil pengujian ditampilkan pada Tabel 3. Parameter yang digunakan adalah parameter terbaik dari hasil pelatihan sebelumnya yaitu pada jaringan utama dengan arsitektur $=12-3-1$ dan pada sub jaringan dengan arsitektur 3-5-1.

Tabel 5 Hasil pengujian jaringan syaraf tiruan hybrid

\begin{tabular}{|c|c|c|c|}
\hline Arsitektur & MSE & Target & Output \\
\hline $3-5-1$ & 0.068078 & 0.1976 & 0.2416 \\
\hline $12-3-1$ & 0.055946 & 0.4603 & 0.4049 \\
\hline
\end{tabular}

Perbandingan nilai MSE pada saat pelatihan dan pengujian dapat dilihat pada Tabel 6.

Tabel 6 Perbandingan MSE hasil pelatihan dan pengujian jaringan syaraf tiruan hybrid

\begin{tabular}{|c|c|c|}
\hline Arsitektur & MSE Pelatihan & MSE Pengujian \\
\hline $3-5-1$ & 0.042797 & 0.068078 \\
\hline $12-3-1$ & 0.038288 & 0.055946 \\
\hline
\end{tabular}

Perbandingan hasil pelatihan dengan pengujian bila dilihat dari nilai MSE memiliki perbedaan yang cukup signifikan. Nilai MSE hasil pengujian lebih besar daripada hasil pelatihan.

Hasil pengujian antara jaringan hybrid JST - PSO dengan JST saja terlihat perbedaan dimana pada JST yang menggunakan back propagation untuk melatih bobot memiliki performa yang lebih baik dari pada jaringan hybrid JST - PSO.

\section{KESIMPULAN}

Dari hasil penelitian dan pembahasan yang telah dilakukan dapat ditarik beberapa kesimpulan.

1. Particle Swarm Optimization mampu digunakan untuk melatih bobot pada jaringan syaraf tiruan, walaupun performanya tidak sebaik metode backpropagation.

2. Velocity yang tepat pada PSO mempengaruhi hasil dari performa jaringan, dari penelitian diperoleh velocity terbaik adalah 0,3 dan 0,4 , begitu juga dengan learning rate pada backpropagation yang terbaik dari hasil penelitian adalah 0,3 dan 0,5 . 
3. Jumlah hidden layer pada jaringan juga mempengaruhi performa dari jaringan. Pada jaringan hybrid berdasarkan hasil penelitian jumlah hidden terbaik adalah 3 dan 5, sedangkan pada jaringan backpropagation jumlah hidden terbaik adalah 4 dan 5.

4. Input time lag pada jaringan hybrid yang terbaik adalah t-2 sedangkan pada jaringan backpropagation $\mathrm{t}-3$.

\section{SARAN}

Diharapkan melakukan penelitian pengaruh algoritma optimasi yang lain sepereti Algoritma Genetika, Ant Colony Optimization, Bee Colony Optimization.

\section{DAFTAR PUSTAKA}

[1] Isa,I.S, Omar,S., Saad,Z., Noor,N.M. dan Osman, M. K., 2010, Weather Forecasting Using Photovoltaic System and Neural Network, Second International Conference on Computational Intelligence, Communication Systems and Networks, pp. 96-100.

[2] Xin-hui,D., Feng, T. dan Shao-qiong,T., 2010, Study of Power System Short-term Load Forecast Based on Artificial Neural Network and Genetic Algorithm, International Conference on Computational Aspects of Social Networks, pp. 725-728.

[3] Kolhe, M., Lin ,T. C. dan Maunuksela,J., 2011, GA-ANN for Short-Term Wind Energy Prediction, Power and Energy Engineering Conference (APPEEC), pp. 1-6.

[4] Ernawati, Perbandingan Algoritma Ant System, 2010, Bee Colony Optimization, dan Particle Swarm Optimization untuk Prediksi Data Time Series Finansial, Program Studi S2 Ilmu Komputer, Jurusan Ilmu Komputer dan Elektronika, Fakultas Matematika Dan Ilmu Pengetahuan Alam, Yogyakarta.

[5] Redjeki,S., 2005, Prediksi Tingkat Inflasi Menggunakan Pendekatan Jaringan Syaraf Tiruan, Program Studi S2 Ilmu Komputer, Jurusan Ilmu Komputer Dan Elektronika, Fakultas Matematika Dan Ilmu Pengetahuan Alam,, Yogyakarta.

[6] Hadavandi, E., Ghanbari,A. dan Naghneh S.A, Developing a Time Series Model Based On Particle Optimization for Gold Price Forecasting,Third International Conference on Business Intelligence and Financial Engineering, pp. 337-340, 2010.

[7] Chang,J.F., Kuan,C.M., dan Lin,Y.W., Forecasting Exchange Rates by Genetic Algorithms Based Back Propagation Network Model, Fifth International Conference on Intelligent Information Hiding and Multimedia Signal Processing, pp. 791-794, 2009. 
[8] Lidya, 2011, Analisis Faktor-Faktor yang Mempengaruhi Ekspor Indonesia tahun 19882008, Program Studi Magister Manajemen, Fakultas Ekonomika Dan Bisnis,, Yogyakarta.

[9] Neto,M., Petry,G.G., J. A. R. L. dan Ferreira, T. A. E., 2009, Combining Artificial Neural Network and Particle Swarm System for Time Series Forecasting, International Joint Conference on Neural Networks, pp. 2230-2237. 